\title{
Erratum to: Contribution of membrane localization to the apoptotic activity of PUMA
}

\author{
Karen S. Yee $\cdot$ Karen H. Vousden
}

Published online: 8 November 2012

(C) Springer Science+Business Media New York 2012

\section{Erratum to: Apoptosis (2008) 13:87-95}

DOI 10.1007/s10495-007-0140-2

The authors have noticed an error in Fig. 3A, which contained an incorrect version of the input control for $\mathrm{Bcl} 2$ expression (lower panel). The correct figure is shown, the conclusions remain unchanged. We apologize for this mistake.
The online version of the original article can be found under doi:10.1007/s10495-007-0140-2.

K. S. Yee $\cdot$ K. H. Vousden $(\bowtie)$

The Beatson Institute for Cancer Research,

Garscube Estate, Switchback Road, Bearsden,

Glasgow G61 1BD, UK

e-mail: k.vousden@beatson.gla.ac.uk

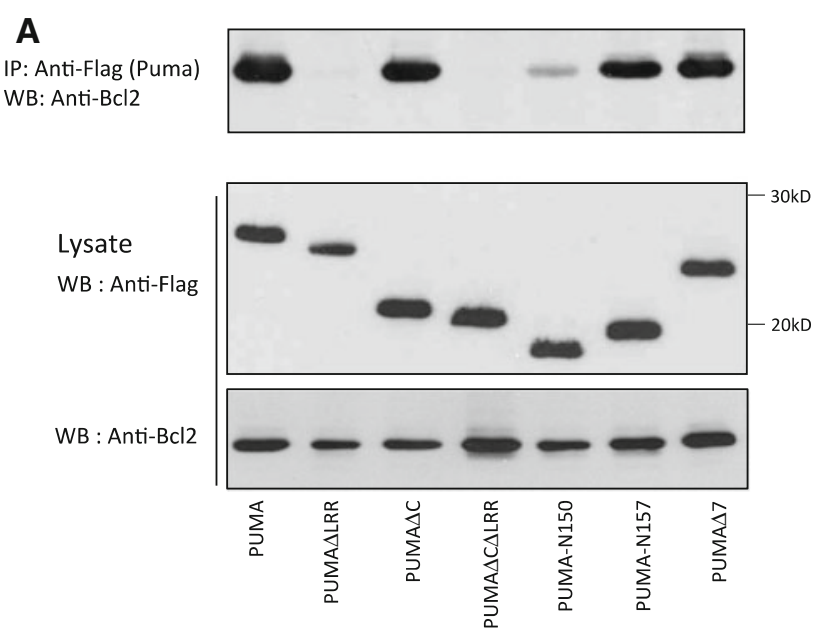

Fig. 3 Interaction of PUMA mutants with Bcl2: (A) Flag-tagged proteins were immunoprecipitated from U2OS cells following transient transfection with pcDNA-Bcl2 and the indicated Flagtagged PUMA expression plasmids. The immunoprecipitates were subjected to SDS PAGE followed by Western blotting to detect Bcl2. Western blotting of cell lysates confirmed expression of each protein 